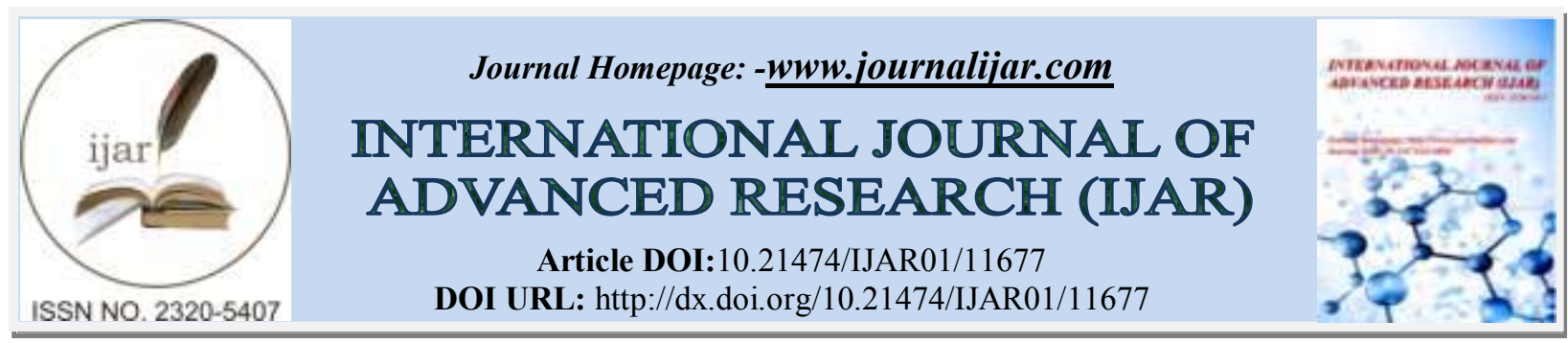

RESEARCH ARTICLE

\title{
INVESTOR ATTITUDE TOWARDS INDIAN FIN-TECH COMPANIES USING ANALYTICAL HIERARCHY PROCESS (AHP)
}

\section{Dr. Syed Noorul Shajar ${ }^{1}$ and Dr. Mazhar Iqbal ${ }^{2}$}

1. Assistant Professor, Department of Commerce, School of Social Science and Humanities, B.S.Abdur Rahman Crescent Institute of Science and Technology, Chennai, Tamilnadu, India.

2. Assistant Professor, Glocal School of Business \& Commerce, Glocal University, Saharanpur, Uttar Pradesh.

\section{Manuscript Info}

Manuscript History

Received: 10 July 2020

Final Accepted: 14 August 2020

Published: September 2020

\section{Key words:-}

Fin-Tech, AHP Approach, Investor, Investment Attitude and Survey Method

\section{Abstract}

The major intend of this research is to find out the investor attitude towards Indian fin-tech companies. The nature of the research is exploratory method, and the sample size is 114 investors in Chennai city, Tamilnadu, India and data collection method used in the research is "Survey Method" through questionnaire. Data have been analyzed by using MS Excel. Findings, suggestions and conclusions were made by keeping an eye on the research problem, variables and objectives.

Copy Right, IJAR, 2020,. All rights reserved.

\section{Introduction:-}

Indian Fin-Tech organizations could address a couple of the basic issues burdening Indian budgetary administrations increment outreach, improve client experience, decrease operational grinding, and encourage selection and utilization of the computerized channel. Heritage inclined cycles and higher working cost models of officeholder banks and monetary specialist co-ops will give computerized FinTech organizations an edge, as banks play find these more agile and creative new businesses. The open door for FinTech lies in growing the market, forming client conduct, and affecting long haul changes in the monetary business. The FinTech new businesses are probably going to lessen costs and improve nature of money related administrations. Not being troubled with inheritance activities, IT frameworks, and costly physical systems, advantages of less fatty working models can be given to clients. The FinTech business will create novel and imaginative models of surveying hazards. Utilizing large information, AI, and elective information to guarantee credit and create FICO assessments for clients with restricted record of loan repayment will improve the infiltration of budgetary administrations in India. FinTech will make a more different, made sure about, and stable budgetary administrations scene.

FinTech organizations are less homogenous than officeholder banks and offer incredible learning layouts to improve, both, capacities and culture. As per the report of (KPMG 2016), India is changing into unique environment offering fintech new companies a stage to possibly develop into billion-dollar unicorns. From tapping new portions to investigating unfamiliar business sectors, fintech new companies in India are seeking after numerous desires. The Indian fintech programming market is anticipated to contact USD 2.4 billion by 2020 from a current USD 1.2 billion, according to NASSCOM. The customarily money driven Indian economy has reacted well to the fintech opportunity, basically set off by a flood in web-based business, and Smartphone entrance. The exchange in incentive for the Indian fintech division is assessed to be around USD 33 billion out of 2016 and is estimated to reach USD 73 billion out of 2020 developing at a five-year CAGR of 22 percent. The financial specialist consideration has been concentrated towards hi-tech urban communities in 2015, with Bengaluru seeing eleven VC-upheld venture arrangements of USD 57 million, trailed by Mumbai and Gurgaon with nine and six arrangements, separately. 
Bengaluru, the beginning up capital of India has profited by the equivalent and is positioned 15 among the world's significant beginning up urban areas. India's development wave may at present not be of the scale when seen against its worldwide partners, however it is stacked well, to a great extent because of a solid ability pipeline of simple toenlist and cheap tech workforce. From wallets to loaning to protection, the administrations of fintech have reclassified the manner by which organizations and customers do routine exchanges. The expanding selection of these patterns is situating India as an appealing business sector around the world.

\section{Analytical Hierarchy Approach (AHP)}

The Analytic Hierarchy Process (AHP) is a technique for sorting out and dissecting complex choices, utilizing math and brain research. It was created by Thomas L. Saaty during the 1970s and has been refined from that point forward. It contains three sections: a definitive objective or issue you're attempting to fathom, the entirety of the potential arrangements, called options, and the models you will pass judgment on the options on. AHP gives an objective structure to a required choice by evaluating its standards and elective alternatives, and for relating those components to the general objective.

Partners analyze the significance of models, two at once, through pair-wise examinations. Model, do you care about occupation benefits or having a short drive more and by what amount more? AHP changes over these assessments into numbers, which can be contrasted with the entirety of the potential models. This measuring ability recognizes the AHP from other dynamic procedures. In the last advance of the process, mathematical needs are determined for every one of the elective choices. These numbers speak to the most wanted arrangements, in view of every one of clients' qualities.

\section{Literature Review:-}

The different endeavors have been made by scientists to recognize the kinds of data that investors need to pick a clear offer. These investigations have experimentally recognized the persuasive factors in picking various stocks by looking over the conduct of individual investors. Potter (1971) and Baker and Haslem (1974) watched a few benefit factors, for example, profits, fast development and brisk benefits alongside different factors, for example, speculation for sparing purposes and long-term development were exactly recognized as viable components on the perspectives of individual investors in settling on venture choices.

Dwindle (1970) completed an examination to distinguish those elements which persuade or manage the venture choices of the little stock investors. The examination distinguished factors, for example, salary from profits, fast development, deliberate venture as a defensive outlet of reserve funds and Professional speculation board. In an investigation, Naser et al. (2003) found that singular investors order the yearly report as the second most significant wellspring of data and institutional investor's rank yearly reports as the fundamental wellspring of data.

Shanmugam (1990) contemplated a gathering of 90 investors to analyze the components influencing venture choice. The examination zeroed in its investigation on the venture objective and the degree of mindfulness on factors influencing speculation choice. The investigation found that the Indian investors were high daring people. The investors had satisfactory information on government guidelines, financial and monetary strategy. Krishnan and Booker (2002) investigated the impacting factors on choices of those investors who utilize examiner's proposals to show up at a momentary choice for holding or selling a distinct stock.

Bennet and Selvam (2011) discovered that SPERTEL chances had affected the estimation of value partakes in the market. The market factors had impacted the stock choice of little investors in India. Bennet et al. (2011) completed an examination and found that a large portion of the investors anticipate that the stock costs should go up to a degree more prominent than the greater part of their ventures. On the off chance that the market has gone down, they figure it would bounce back. On the off chance that the market is up, they figure it would go further. In either case, they settle on venture choice by virtue of the presumption that the securities exchange would give better returns. The writing on investor's feeling is still in its outset, and much stays to be found and learnt. There is no complete investigation in India and especially in Visakhapatnam, zeroing in on market explicit components that impact investor's conclusion. Subsequently this examination, with the essential goal of investigating information on investors perspectives and observations about venture choices and to recognize the market explicit elements that impact investors stock determination choices. 


\section{Methods:-}

The major intend of this research is to find out the investor attitude towards Indian fin-tech companies. The nature of the research is exploratory method, and the sample size is 114 investors in Chennai city, Tamilnadu, India and data collection method used in the research is "Survey Method" through questionnaire. Data have been analyzed by using MS Excel. Findings, suggestions and conclusions were made by keeping an eye on the research problem, variables and objectives.

\section{Results And Discussions:-}

The outcomes of the constructs depict uniformity proportion as $41.2 \%$ and also primary eigen value is 18 which is the outcome of 10.0 versions. The priority weight of criteria $\&$ characteristic is determined making use of the eigen vector technique afore-mention initially, a set wise comparison matrix is created for every crucial variable, and afterwards the resultant matrix is normalized to unify the outcome. The resulting weights for the standards based on pair-wise contrasts are presented in the table 1.

Table 1:- Decision Matrix.

\begin{tabular}{|r|r|r|r|r|r|r|r|}
\hline & 1 & 2 & 3 & 4 & 5 & 6 & 7 \\
\hline 1 & 1 & 9.00 & 8.00 & 7.00 & 6.00 & 5.00 & 4.00 \\
\hline 2 & 1.00 & 1 & 8.00 & 7.00 & 6.00 & 5.00 & 4.00 \\
\hline 3 & 0.14 & 0.11 & 1 & 7.00 & 6.00 & 5.00 & 4.00 \\
\hline 4 & 0.13 & 1.00 & 0.12 & 1 & 6.00 & 5.00 & 4.00 \\
\hline 5 & 0.12 & 0.11 & 0.14 & 0.13 & 1 & 5.00 & 4.00 \\
\hline 6 & 0.11 & 0.12 & 0.15 & 0.14 & 0.17 & 1 & 4.00 \\
\hline 7 & 0.10 & 0.13 & 0.13 & 0.16 & 0.16 & 0.16 & 1 \\
\hline
\end{tabular}

These are the resulting weights for the criteria based upon pairwise contrasts

Table 2:- Priorities.

\begin{tabular}{|r|r|r|r|}
\hline & Category & Priority & Rank \\
\hline 1 & Risk Factors & $34.0 \%$ & \\
\hline 2 & Returns & $26.8 \%$ & \\
\hline 3 & Growth & $16.8 \%$ & 2 \\
\hline 4 & Dividend & $13.4 \%$ & 3 \\
\hline 5 & Maturity Period & $3.8 \%$ & \\
\hline 6 & Time Horizons & $2.8 \%$ & \\
\hline 7 & Volatility & $1.4 \%$ & \\
\hline
\end{tabular}

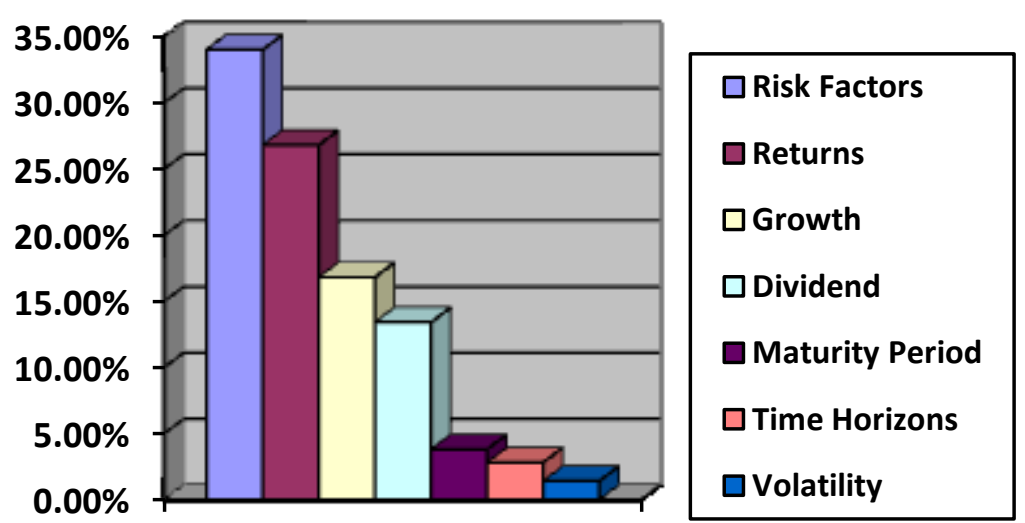

Figure 1:- Priorities. 
The table 2 shows the ranking of priorities based on eigen vector method. Accordingly, Risk Factors is the priority (34.0\%) with no. 1 rank. the second rank is Returns with $26.8 \%$ followed by Growth with priority as $16.8 \%$ as third rank. the fourth and fifth rank is Dividend (13.4\%) and Maturity Period (3.8\%) respectively.

\section{Conclusion:-}

The term 'Fintech', the short type of the expression monetary innovation signifies industry that encompasses organizations which use innovation for effective conveyance of budgetary administrations. It is a rising kind of administration in this 21 st century. The new beginning-up organizations are attempting to supplant the customary exchange framework with the new, compelling strategies by applying innovation in budgetary parts for portable instalments, advances, cash moves and, in any event, for resource the board. Some more instances of innovation applied to the monetary exchanges are distributed loaning, shared instalment innovation, advanced wallets, Square chain and portable banking. The points will help in bringing further advantages and accomplishing high productivity for the budgetary exchanges. They likewise help to decrease costs caused for clients. In all sections of money related administrations there is a plenty of Blade Specialists rising in India. By watching the pace of blade specialist's development, the way that India has huge enterprising potential can't be denied. There are around 1500 Blade Tech startup firms working in India, and of these, almost half were begun in the previous two years. Both actually and monetarily the blade tech firms should be prepared well. We can see a larger part of effective new businesses in an instalments space and it is normal and equivalent with the other budgetary portions too. The balance tech industry should be energized further with various activities by the legislature and other administrative bodies.

\section{References:-}

1. Agapova, Anna, 2011, "The Role of Money Market Mutual Funds in Mutual Fund Familiese, Journal of Applied Finance, Vol. 21, Issue. 1, pp. 87-102.

2. Agarwal, Vikas; Boyson, Nicole M.; Naik, Narayan Y, 2009, Hedge Funds for Retail Investors, An Examination of Hedged Mutual Funds, Journal of Financial \& Quantitative Analysis, Vol. 44, Issue 2, pp. $273-$ 305.

3. Anand, S. and Murugaiah,V. (2004), Marketing of financial services: strategic issues, SCMS Journal of Indian Management.

4. Bennet, E., Selvam, M., Indhumathi, G., Ramkumar, R. R., \&Karpagam, V. (2011). Factors influencing retail investors' attitude towards investing in equity stocks: A study in Tamil Nadu. Journal of Modern Accounting and Auditing, 7(3), 316.

5. Bansal L K and Gupta R K (1992) "Mutual Funds: A Case study of Master Share of Unit Trust of India", The Indian Journal of Commerce Vol. XLV (II), June, pp.89-96.

6. Dash, A. (2013). Technological Revolution and Its Implication on Customer Value Perception: A Study on Indian Banking Sector. International Journal of Innovative Research and Development, 2(12).

7. Gauri Prabhu \& Dr. N.M. Vechalekar (2014), -Perception of Indian Investor towards Investment in Mutual Funds with Special Reference to MIP Fundsll, IOSR Journal of Economics and Finance (IOSR-JEF), Pp. 66-74.

8. King, J.S., "Mutual Funds: Investment of Choice for Individual Investors?" Review of Business, Vol. 23, No. 3, pp. 35-39, 2002.

9. Krishnan, R., \& Booker, D. M. (2002). Investors' use of analysts' recommendations. Behavioral Research in Accounting, 14(1), 129-156.

10. Mathew, James (2000) "Mutual Funds in India: A Study", Southern Economist, Vol. 39(7) August, pp.3-5.

11. Panda, Tapan K and Tripathy, Nalini Prava (2001) "Customer Orientation in Designing Mutual Fund Products", The ICFAI Journal of Applied Finance, Vol. 7(4), (September) pp.20-28.

12. Ramamurthy, B. M. and Reddy, S. (2005), Recent Trends in Mutual Fund Industry, SCMS Journal of Indian Management.

13. Shajar, S. N. (2017). Relationship between Working Capital Management and Profitability of Automobile Companies in India: A Paradigm Shift towards Economic Strengthening. International Journal of Trade, Economics and Finance, 8(4).

14. Shajar, S. N. (2018). IMPACT OF WORKING CAPITAL POLICIES ON MARKET VALUE OF FIRM: A STUDY OF SELECTED INDIAN MANUFACTURING COMPANIES.

15. Singh, B. K. and Jha, A.K. (2009), "An empirical study on awareness \& acceptability of mutual fund", 49-55, Regional Student"s Conference, ICWAI.

16. Singh, B. K. and Jha, A.K. (2009), "An empirical study on awareness \& acceptability of mutual fund", 49-55, Regional Student"s Conference, ICWAI. 
17. Sondhi, H. J., Jain, P. K., "Financial Management of Private and Public Equity Mutual Funds in India: An Analysis of Profitability", The ICFAI Journal of Applied Finance, Vol. 2, No. 6, pp. 14-27. 2005.

18. Syama Sundar, P.V. (1998). "Growth prospects of mutual funds and investor perception with special reference to Kothari pioneer mutual fund", Project Report, Sri Srinivas Vidya Parishad, Andhra University, Visakhapatnam. 